\title{
A SEMANA SANTA NOS TERREIROS: UM ESTUDO DO SINCRETISMO RELIGIOSO EM BELÉM DO PARÁ ${ }^{1}$
}

\author{
THE HOLY WEEK IN TERREIROS: \\ A STUDY OF RELIGIOUS SYNCRETISM IN BELÉM OF PARÁ
}

\author{
SEMANA SANTA EN TERREIROS: \\ UN ESTUDIO DEL SINCRETISMO RELIGIOSO EN BELÉM DO PARÁ
}

\begin{abstract}
Resumo
O presente artigo, escrito no contexto das discussões acadêmicas pelos 100 anos da abolição da escravatura no Brasil (1988), retomava o clássico tema do sincretismo religioso afrocatólico buscando ir além da explicação de que as entidades africanas somente puderam ser cultuadas porque foram disfarçadas sob o manto dos santos católicos; o que implicava dizer que o sincretismo ocorrera apenas no plano santoral do calendário litúrgico católico. Sabendo-se, porém, que as festas cristocêntricas precedem em importância a memória dos santos, e sabendo-se ainda da existência da importante associação sincrética entre o Orixá Oxalá e Jesus Cristo, o artigo deslocou sua análise para a chamada "semana santa" que corresponde ao plano do tempo litúrgico católico buscando explorar o resultado do encontro dessa experiência histórica de aculturação coercitiva ocorrida ao longo da escravidão. Metodologicamente o artigo se baseou em pesquisa de campo com a utilização da técnica de observação participante em terreiros de tradição Mina Nagô $e$ Umbanda da comunidade religiosa de Belém. Nessa observação foi privilegiada a vivência da semana santa no interior das casas de culto pesquisadas.
\end{abstract}

Palavras-chave: Semana Santa. Sincretismo, Sincretismo Afrocatólico. Terreiros.

\begin{abstract}
The present paper, written in the context of academic discussions for the 100 years of the abolition of slavery in Brazil (1988), took up the classic theme of Afro-Catholic religious syncretism, seeking to go beyond the explanation that African entities could only be worshiped because they were disguised under the robe of Catholic saints; and, which implied that syncretism had occurred only on the sanctuary level of the Catholic liturgical calendar. Knowing, however, that the Christ-centered festivals precede in importance the memory of the saints, and also knowing the existence of the important syncretic association between the Orixá Oxalá and Jesus Christ, this paper has displaced its analysis to the so-called "Holy Week" which corresponds to the Catholic liturgical time plan, seeking to explore the result of the encounter of this historical experience of coercive acculturation that occurred during slavery. Methodologically, the article was based on field research using the technique of participant observation in traditional Mina Nagô and Umbanda terreiros in the religious community of Belém. This observation privileged the experience of the Holy Heek inside the houses of worship researched.
\end{abstract}

Key words: Holy Week. Syncretism. Afro-Catholic Syncretism. Terreios

\footnotetext{
${ }^{1}$ Este texto foi apresentado no Congresso Internacional sobre Escravidão, promovido pelo MPEG/CNPq/USP, realizado em Belém do Pará, em maio/1988.

${ }^{2}$ Antropóloga, Professora aposentada da Universidade Federal do Pará (UFPA) e Presidente de Instituto Histórico e Geográfico do Pará (IHGP). E-mail: anaizavergolino@gmail.com
} 


\section{Resumen}

El presente artículo, escrito en el contexto de las discusiones académicas por los 100 años de la abolición de la esclavitud en Brasil (1988), retomó el tema clásico del sincretismo religioso afro-católico, buscando ir más allá de la explicación de que las entidades africanas solo pueden ser adoradas porque están disfrazadas bajo el manto de los santos católicos; lo que implicaba que el sincretismo había ocurrido solo en el nivel del santuario del calendario litúrgico católico. Sabiendo, sin embargo, que las fiestas cristocéntricas preceden en importancia a la memoria de los santos, y conociendo también la existencia de la importante asociación sincrética entre los Orixá Oxalá y Jesucristo, el artículo desplazó su análisis a la llamada "semana santa" que corresponde a la plan del tiempo litúrgico católico que busca explorar el resultado del encuentro de esta experiencia histórica de aculturación coercitiva que se produjo durante la esclavitud. Metodológicamente, el artículo se basó en una investigación de campo utilizando técnicas de observación participante en los sitios religiosos tradicionales Mina Nagô y Umbanda de la comunidad religiosa de Belém, en esta observación se privilegió la experiencia de la Semana Santa dentro de los templos de investigación.

Palabras Clave: Semana Santa. Sincretismo. Sincretismo Afrocatólico. Terreiros

\section{INTRODUÇÃO}

À primeira vista pode parecer repetitivo voltarmos a falar sobre o sincretismo afrocatólico. Esse tema já foi tão estudado que às vezes temos a impressão de que não há mais nada a dizer sobre ele. Mas, no muito que já foi dito, o conceito aparece quase sempre menosprezado, sobretudo quando o investigador parte do pressuposto de que existem religiões afro-brasileiras puras, onde o modelo é o Candomblé Nagô, e cultos misturados, onde o sincretismo fica incluído. O fenômeno causa polêmica, divide opiniões, e, na visão de alguns pesquisadores e adeptos defensores da ortodoxia Nagô, o praticante de um culto sincrético como a Umbanda é, na verdade, portador de um quase-estigma religioso.

Longe dessa discussão, minha opinião é exatamente inversa, ou seja, além de achar que ainda há muito a se dizer sobre sincretismo, não o considero uma degeneração ou deturpação de qualquer tradição pura e, sim, um fenômeno profundo, diria mesmo fundamental, no sentido filosófico do termo. O problema é que, talvez por razões de preconceito, temos esquecido que qualquer tradição sincrética pode ser considerada uma religião se ela responder às necessidades das pessoas. Pode-se dizer que, se um produto sincrético se torna funcional, ele não é mais um sincretismo no sentido estreito do termo; portanto, tudo vai depender da forma com que olhamos o fenômeno: se de um ponto de vista histórico ou funcional. Em outras palavras, se considerarmos o ponto de vista dos adeptos, veremos que o seguidor de uma religião sincrética nunca vivencia uma fé como uma mistura de duas ou mais religiões (RINGGREN, 1969, p.13). Acontece que, ainda presos a uma visão preconceituosa, não temos mergulhado na profundidade desse fenômeno; ao contrário, temos ficado na sua superfície à medida que continuamos definindo o sincretismo como mera associação forçada entre santos católicos e orixás africanos ${ }^{3}$.

\footnotetext{
${ }^{3}$ Essas associações também pretendem dar conta da origem do fenômeno: os escravos teriam visto nas litografias dos santos católicos os mesmos atributos dos orixás africanos, ou encontrado paralelismo entre as lendas dos santos e os 
Observando-se, porém, as variantes dessas associações, torna-se fácil constatarmos a complexidade do fenômeno. Assim, por exemplo, enquanto em alguns estados do Brasil se festeja Oxóssi no dia 20 de janeiro, dia em que a Igreja Católica louva em "memória facultativa" o santo mártir São Sebastião ${ }^{4}$, em outros locais Oxóssi é celebrado no dia 23 de abril, data em que no calendário católico se venera a São Jorge, um dos mártires do cristianismo, morto na Capadócia, século IV. E, mais ainda, Oxóssi também é comemorado no dia da solenidade de Corpus Christi, o que torna a festa daquele orixá uma data móvel ao sabor do calendário católico ${ }^{5}$. Essas variantes correm por conta das diferentes tradições afro-brasileiras existentes em nosso território.

Como se percebe, apesar de a realidade reclamar um exame mais acurado do fenômeno, penso que continuamos excessivamente repetitivos em nossos estudos sobre o sincretismo. De minha parte estou plenamente convencida de que, no Brasil, a comunicação entre catolicismo e africanismo extrapola o plano das relações entre santos e orixás. Venho observando, por exemplo, que, nos cultos afro-brasileiros de Belém, reconhece-se também a importância da Semana Santa ${ }^{6}$. Os terreiros de diferentes tradições incorporam no seu calendário aquelas datas da Quaresma. Essa incorporação vai indicar, então, que a relação entre os dois sistemas de crenças também se dá no plano do Tempo, um plano que é mais interno, mais conceitual, ou, se preferirmos, um plano que é o da essência e não da aparência ${ }^{7}$.

A presença da Semana Santa no calendário dos cultos afros já foi notada por outros pesquisadores da América Latina, porém não foi analisada pela literatura especializada ${ }^{8}$. Pensamos que a pouca importância conferida ao dado talvez se explique pela relevância que ainda cerca a tese da máscara colonial, a qual

mitos dos orixás; ou, ainda, o sincretismo teria surgido das relações em comum que santos e orixás possuem com diferentes forças da natureza.

${ }^{4}$ As datas do calendário católico são caracterizadas como: F - Festa (Festum), S- Solenidade (Sollemnitas), M Memória obrigatória (Memoria obligatoria), m - Memória facultativa (Memoria ad libitum). A tabela dos dias litúrgicos, segundo sua ordem de precedência, se encontra nos Diretórios Litúrgicos, uma publicação anual da CNBB.

${ }^{5}$ A Solenidade do Santíssimo Corpo e Sangue de Cristo (Corpus Christi) juntamente com as solenidades da Santíssima Trindade, do Sagrado Coração de Jesus e de Cristo Rei são festas que não possuem data fixa por causa de sua dependência em relação a data da Páscoa. A solenidade de Corpus Christi é realizada na primeira quinta-feira após a festa da Santíssima Trindade, cuja data é móvel porque acontece no domingo seguinte ao Domingo de Pentecostes e este varia em função da data da Páscoa.

${ }^{6}$ Em Belém são praticados os seguintes cultos: Mina-Nagô, Umbanda, Candomblé (com diferentes nações), Omolocô e a Jurema, esta última praticamente absorvida pelo Mina-Nagô. O Mina-Nagô representa a tradição afro do Pará. Nas suas origens é um culto sincrético por ser uma mistura da Casa de Nagô maranhense já influenciada pela Casa das Minas. No Pará o culto teria se misturado com a pajelança; nos anos 1930, recebe a influência da Umbanda; por volta dos anos 1950/1960, a influência do Candomblé (possivelmente Angola). Ao longo de sua evolução, a influência do catolicismo. Recentemente, se observa nova influência do Candomblé, especialmente da "nação" Ketu. A descrição mais recente do campo religioso de Belém se encontra no ensaio de Furuya, citado na bibliografia.

$7 \mathrm{O}$ calendário católico é constituído por dois ciclos, a saber: o Ciclo Temporal, que diz respeito às festas de Nosso Senhor Jesus Cristo e que compreende os chamados de "Tempos" onde se encontra o "Tempo da Quaresma". É plano mais importante porque é nele que se situa a festa da Páscoa. As festas desse plano não possuem datas fixas por dependerem da data da Páscoa que, como sabemos, é móvel (vide nota 11). O outro plano, que é secundário, é o Ciclo Santoral, onde se incluem as festas de veneração dos santos, mas que não se confunde ou reduz ao "Martirológico Romano", o conhecido "santo do dia". As análises do sincretismo, sem observar essas distinções internas, têm privilegiado a relação: santo de branco (católico) versus santo de negro (orixá). Nosso trabalho privilegia o Ciclo Temporal.

${ }^{8}$ Veja-se o trabalho de Angelina Pollak-Eltz (1977, p. 99) citado na bibliografia. 
encontra a gênese do sincretismo no disfarce estratégico que os negros escravos usaram para esconder suas crenças da repressão de seus dominadores ${ }^{9}$. Não nos deteremos nos anacronismos e superficialidades dessa tese, porque esses aspectos já foram apontados por outros pesquisadores ${ }^{10}$. Preferimos chamar a atenção para o fato de que ela não nos permite entender de que forma o calendário católico, em particular a Semana Santa, foi absorvido por terreiros. E aqui seriam necessárias duas palavras sobre o ano litúrgico católico para mostrarmos a importância da Semana Santa no calendário cristão católico.

\section{O ANO LITÚRgICO CATÓLICO}

O ano litúrgico católico está dividido em períodos de duração desigual denominados "Tempos". Estes são cíclicos e se sucedem na seguinte ordem: Tempo do Advento (que abre o ano litúrgico), Tempo do Natal e o Tempo da Quaresma e novamente entre Pentecostes (que acontece 50 dias após a Páscoa) e o Advento, vamos encontrar um período mais longo chamado de Tempo Comum. Dentre esses ciclos, o Tempo da Quaresma é aquele que interessa particularmente ao exame do sincretismo. Ele se inicia na Quarta-Feira de Cinzas e se estende até o Domingo da Ressureição. É um ciclo de penitência por excelência marcado por jejuns e abstinências. É tempo de preparação para a celebração da Páscoa. Dele faz parte a Semana Santa, que, no seu conjunto, visa a recordar a Paixão e a Ressureição de Cristo desde seu ingresso messiânico em Jerusalém (cf. NALC, nº 31, apud Diretório Litúrgico, CNBB, 1986).

O Tríduo Pascal é o ápice de todo o ano litúrgico, e a Vigília Pascal, que acontece na noite de sábado santo, é tida como a "mãe de todas as vigílias". É nela que a Igreja aguarda vigilante a ressureição de Cristo. Ela é também considerada o cume de todo o ano litúrgico (cf.op.cit. p. 178). Complementando o Tempo da Quaresma temos o Tempo Pascal, que corresponde aos 50 dias entre o domingo da Ressureição e o domingo de Pentecostes. O domingo de Pentecostes representa o coroamento e o remate do Tempo Pascal, e esses dias mencionados constituem uma preparação para a vinda do Espírito Santo Paráclito (cf. op. cit. p. 196).

Ora, será exatamente o Tempo da Quaresma - ápice do ano litúrgico católico - que fará a vinculação dos dois calendários, pois esse é um período sagrado reconhecido e respeitado tanto pelo catolicismo quanto pelos cultos afros. O fato de a Quaresma e a Páscoa serem festas móveis coloca ainda a questão de entendermos como é possível o ajustamento desses calendários, quando sabemos que na tradição afro a regra geral é festejar-se as entidades, independentes de suas categorias, em datas fixas. Em suma, eu diria que a questão central na compreensão desse sincretismo é entendermos por que razões os terreiros

\footnotetext{
9 Esta tese evoluiu para uma interpretação bastante política, uma espécie de "tese da resistência", que nega de forma veemente qualquer possibilidade de sincretismo afro-católico. Processos analíticos de aculturação, tais como retenção, sincretização, reinterpretação, bem como a assimilação, não se colocam para essa interpretação. Segundo a mesma, certas modalidades de culto, especialmente o Candomblé Nagô, mantiveram sua herança africana e das contribuições que receberam conservaram apenas aquelas que reforçaram sua "africanidade". Para uma visão relativizada e crítica dessa postura veja-se os trabalhos de Dantas (1982), Fry (1984) e Birman (1984), citados na bibliografia.

${ }^{10}$ Veja-se a comunicação de Motta (1985) e o artigo de Kloppenburg (1984), também citado na bibliografia.
} 
durante a Quaresma se submetem à contagem cristã do tempo, acompanhando o princípio móvel do calendário cristão católico. Eu iria mais longe ao afirmar, a partir de observações, que não se trata apenas de uma justaposição, mas que, de fato, os terreiros assimilaram e reinterpretaram esse calendário.

Uma vez constatada essa realidade empírica, tento encontrar as condições que tornaram possível a mistura dessas religiões, pois, do mesmo modo que Ringren $(1969$, p. 9) penso que as "influências" e os "empréstimos" somente são passíveis de acontecer caso existam pontos de contato ou similaridades entre duas ou mais religiões. Assim sendo, o que venho buscando são as passagens ou comunicações entre as duas tradições aqui consideradas. Devo dizer que, apesar de existir um sincretismo no interior do campo afro que em Belém ainda inclui a pajelança - e do fenômeno também acontecer no plano "Ciclo Santoral", situei minha análise no plano do "Ciclo Temporal", examinando apenas a questão da Quaresma, particularmente a Semana Santa.

\section{A MARCAÇÃO DO TEMPO}

Uma vez que a Quaresma é reconhecida pelos terreiros, fica aberta a possibilidade de alteração em qualquer um dos planos que compõem um calendário afro-brasileiro padrão ${ }^{11}$. Por outro lado, a Quaresma também se impõe na contagem do ano civil, pois sabemos que é ela que marca o início do tempo profano do carnaval $^{12}$. Esse é um dado relevante, porque na verdade é o conjunto Carnaval/Quaresma - esses dois tempos inter-relacionados - que irá provocar uma ruptura no tempo sagrado dos terreiros. Na visão dos terreiros, Quaresma é um tempo cujo início é muito variado, mas se encerra sempre no sábado de Aleluia.

Para muitos terreiros de Belém, especialmente os de Mina-Nagô, a sequência do tempo Carnaval/Quaresma representa a passagem de um chamado "período de euforia" (Tempo do Carnaval) para um "período de meditação" (Tempo da Semana Santa). Esse período de ruptura é marcado por muitas interdições rituais, algumas das quais recaem principalmente sobre o calendário. Não se pode, por exemplo, "fazer toques" (festas públicas com tambor) tanto nos três dias de carnaval quanto no decorrer da Semana Santa. As festas que normalmente recaem nesse período, tais como o "toque" para João da Mata (8 de fevereiro), para Omulu/Obaluaiê (11 de fevereiro), para D. José Rei Floriano (19 de março), para Ogum (23 de abril), e, evidentemente, algumas festas particulares das casas de culto, todas elas estão sujeitas a transferência ou a simples cancelamento.

11 No calendário das casas de culto pode-se observar a existência de datas que são particulares às casas propriamente ditas(homenagem à entidade(s) protetora(s) da casa ou de seu dirigente, obrigações tradicionais da casa,saídas de "iaôs etc) e datas que são reconhecidas a nível nacional, como o 27 de setembro, dia de Ibeji (tradição Nagô), Toçá (tradição Mina-Jejê) e Cosme e Damião (Umbanda). O calendário das casas paraenses possui datas mais locais, ou seja, aquelas reconhecidas apenas em Belém e São Luís - as duas tradições oriundas do modelo Jêje-Nagô. Um caso exemplar seria a festa de D. José Rei Floriano (19 de março), e que parece acontecer apenas em Belém e Manaus.

${ }^{12}$ No Brasil, os festejos pré-carnavalescos têm início com as comemorações da passagem do ano, enquanto o Carnaval propriamente dito se estende do sábado anterior ao Domingo da Quinquagésima até a terça-feira gorda e volta com a Aleluia, quando se realizam bailes semelhantes aos bailes de Momo. 


\section{A semana santa nos terreiros: \\ Um estudo do sincretismo religioso em Belém do Pará}

Nos anos em que essas datas não coincidem com os períodos de interdição já mencionados, as festas são realizadas, mas o pai-de-santo tem de redobrar certos cuidados ritualísticos, porque se atravessa o período da Quaresma.

Obviamente, esse ajustamento de tempos gera dificuldade para os terreiros, a começar pelo entendimento do caráter móvel da Páscoa, cuja gênese histórica e cósmica quase nunca é alcançada ${ }^{13}$. O fato de a Sexta-feira da Paixão, neste ano de 1988, ter coincidido com o $1^{\circ}$ de abril, o popular "dia da mentira", pareceu aos olhos de algumas pessoas uma aberração, um ato intencional e de mau gosto da parte de um sujeito não muito bem definido mas que passava a ser especulado. Opiniões mais ingênuas diziam: "A culpa é dos padres, eles estão acabando com tudo!", uma referência às mudanças litúrgicas ocorridas no catolicismo. Outras vezes, o considerado absurdo reforçava a fé, pois as pessoas aceitavam a estranha mobilidade da data da morte de Cristo porque aquilo era mais uma prova dos muitos "mistérios" que cercavam a figura do "Homem".

Na prática, resta ao pai-de-santo a tarefa de combinar esses vários tempos - é curioso vermos cada um deles de folhinha nas mãos, tentando ajustar o calendário civil com o tempo católico, o tempo dos orixás, o calendário de seu terreiro e ainda o tempo cósmico, uma vez que os quadrantes da Lua tem papel fundamental em certos rituais ${ }^{14}$. Tudo isso para compor um calendário único e que obedeça ao princípio do tempo móvel, o qual é extrínseco ao seu próprio calendário. Mas, esse é um tipo de cálculo imprescindível, sobretudo no momento dos ritos de passagem, qualquer que seja o seu grau. É tudo um cálculo muito delicado, especialmente quando os búzios vaticinam que o rito deve acontecer na primeira metade do ano - e temos bons exemplos desses cálculos meticulosos a envolver dos mais simples aos mais complexos ajustamentos do tempo. Todavia, é preciso frisar que esse sincretismo, que vincula diferentes tempos de diferentes tradições, não se reduz a um simples cálculo; mais reveladoras são as representações construídas em torno desse período do ano.

\section{DO CARNAVAL À ALELUIA}

$\mathrm{Na}$ concepção de uma liderança do Omolocô, uma das tradições afro-brasileiras existentes em Belém:

\footnotetext{
13 A data de celebração da Páscoa cristã foi chamada de "Controvérsia Pascal", polêmica que ocupou a Igreja do século II ao século IV. As Igrejas da Ásia Menor e da Síria pretendiam preservar a data de Páscoa judaica - $14^{\circ}$ dia do mês Nisã, ou o $1^{\mathrm{o}}$ dia da $1^{\mathrm{a}}$ lua cheia do $1^{\circ}$ mês lunar após o equinócio da primavera. Como não importava o dia da semana, esta data negava o significado de domingo, já então considerado pela cristandade como o "Dia do Senhor". A questão somente se resolve no Concílio de Nicéia *325 a.D.), quando fica definida a data de celebração: $1^{\circ}$ domingo depois da $1^{a}$ lua cheia da primavera. Essa controvérsia no fundo envolve um complexo cálculo astronômico de ajustamento do calendário lunar (tradição judaica) e outro solar (tradição cristã). Se prestarmos atenção, a data da Páscoa, sendo móvel, mantém o princípio lunar da tradição judaica ao mesmo tempo que oscila de 22 de março a 25 de abril, datas balisadas pelo calendário cristão.

${ }^{14}$ Por exemplo, nas "lavagens de cabeça", uma "fortificação" para a mediunidade e que é realizada mensalmente. Ela geralmente é feita na "força da lua" crescente ou cheia, evitando-se as luas minguante e nova.
} 


\section{A semana santa nos terreiros: \\ Um estudo do sincretismo religioso em Belém do Pará}

(...) Quaresma é um período, que a falange do mal predomina (...) dando origem aos mais sérios conflitos em cumprissões e até crimes neste planeta (...) nós observamos que parece nesta época após a Quaresma, após o Carnaval, grandes crimes, grandes conflitos eu tenho observado se realizando no mundo (...) Durante a Quaresma o sol se esconde muitas vezes e nós sabemos que é treva para aqueles que vivem nas trevas. Existem pessoas que não respeitam esta época sagrada por desconhecerem totalmente os efeitos da natureza, do mundo dos espíritos presentes (...) Estes dias nunca serão iguais aos demais por representarem os 49 dias em que Cristo sofreu neste planeta (Mãe Adair Valente, Liderança Omolocô, 1986)

Essa ideia do perigo está apoiada na crença de que a cada ano, no período que se estende do Carnaval à Aleluia, acontece a partida temporária de todos os orixás e demais entidades dos diferentes panteões ou para a África (se a tradição é o Candomblé), ou para Aruanda (demais tradições), de lá retornando somente no sábado de aleluia. Esse é um período que as entidades não podem ajudar seus filhos, já que os sacrifícios e vários trabalhos ficam suspensos.

Existem variações em torno do dia, mas tanto a entrada quanto a saída desse período devem ser cercadas de cuidados rituais. No Candomblé, a cerimônia de entrada no ciclo chama-se Lorogun e acontece quase sempre no primeiro domingo após o carnaval. Nas demais tradições, simplesmente "encosta-se" temporariamente o tambor na semana anterior ao Carnaval. Praticantes do Mina - Nagô explicam o perigo, nos seguintes termos:

(...) No Carnaval, o Exú está em liberdade, ele não está submisso àquele vinculação que eles têm com as entidades; então as casas correm o risco de verem suas "defesas" enfraquecidas, porque ele é a principal "defesa" da casa, porque justamente ele é o elemento de ligação entre o ser humano e as entidades; sem ele não há comunicação perfeita (Pai Beto, praticante do Mina-Nagô, 1986)

Então, alternativas de "defesa" são buscadas:

(...) Na época do carnaval, Exu não fica submisso, então o pai-de-santo tem que usar de fundamentos rituais para que haja uma substituição de "defesa". Nesse caso, há o reforço do seu Exu pessoal - o Lonã-, e quem passa a ser o defensor da casa é o próprio pai-desanto (Juvenal Barbosa - Presidente da Federação Espirita Umbandista dos Cultos Afros do Pará - 1986)

A ideia de perigo é dupla porque, além dos riscos da "fraqueza", existem ainda os riscos da traição, pois como me disse certo líder incorporado com seu "guia-de-frente".

(...) essa é a época preferida dos bruxos, pessoas que trabalham na Quimbanda ou magia negra (...) o período que se estende do Carnaval até às três horas da agonia da Sexta-Feira da Paixão (...) é o mais propício para trabalhos da magia em geral, ainda mais quando se sabe que todo e qualquer terreiro tem os seus rivais (Mãe Adair Valente, Liderança Omolocô, 1986)

Com a ordem assim ameaçada, um mínimo de segurança pode ser obtido se o médium "agradar" (fizer ofertórios) Exu. Por quê?

Porque, primeiro, não existe uma forma de você prender o Exu nesse período do Carnaval. Segundo, como você tem conhecimento de que o Exu está cumprindo missão que lhe é inerente, você tem que, de uma forma ou de outra, demonstrar que você aceita aquilo como 
normal, demonstrar seu carinho, compreensão com aquelas forças, e a forma que você tem é dando a ele o agrado de costume de cada um (comida seca, sangue, bebida, etc..)( Mãe Adair Valente, Liderança Omolocô, 1986)

Como ratificou certo líder Mina-Nagô durante o Carnaval de 1988:

Exu se liberta, sim, mas eu já bati o tambor de Obaluaiê, despachei ele (...) fiz só comida seca para Exu; no outro dia, levantei [retirei o ofertório], porque já estava contando no domingo gordo (Pai Beto - Líder Mina-Nagô, 1988)

Assim fazendo, ele garante um mínimo de "proteção" para si mesmo ao afirmar: "Exu já tá liberto, mas com o pai-de-santo não atinge nada, porque fortificamos ele, desde janeiro alimentamos ele (...)". E se o médium não "agradar" Exu? "Se o médium não agradar pode acontecer morte, receber facada, ir preso, para Exu não se tem forças (...)”.

O Exu é "recolhido" na Quarta-Feira de Cinzas, mas a ordem não se restabelece totalmente porque as outras divindades permanecerão ausentes e longe, prolongado por mais quarente dias a agonia de desproteção entre os homens. E assim os terreiros entram no "período da meditação", que, em termos mais específicos, significa Semana Santa. Do mesmo modo que a entrada e a saída do Carnaval, aqui também são necessários ritos especiais que serão mais ou menos elaborados dependendo da tradição e da casa consideradas.

Um aspecto importante a ser ressaltado, e que estabelece um contraste entre o catolicismo e africanismo, é a valorização desigual dos dias da Semana Santa. Por exemplo, enquanto no catolicismo os dias mais significativos são o Domingo de Ramos (que rememora a entrada messiânica de Cristo em Jerusalém), a Sexta-Feira da Paixão (dia de sua agonia e morte) e o Domingo de Páscoa (dia de sua gloriosa ressurreição); a tradição afro de Belém (Mina Nagô) vai valorizar a Quinta-Feira Santa, a Sexta-Feira da Paixão e o Sábado de Aleluia, deixando claro que os domingos são dias "vazios" na percepção dos terreiros.

Assim, apesar de existir o reconhecimento de uma estrutura que se mostra comum, observa-se ao mesmo tempo uma valorização diferente das partes dessa estrutura. Vejamos então em que consiste o "tríduo" dos terreiros, tentando apreender seu universo através da interpretação daquilo que chamamos de "liturgia simbólica".

\section{O "TRÍDUO" DOS TERREIROS: UMA LITÚRGIA SIMBÓLICA}

\section{A Quinta-Feira Santa}


Na liturgia de algumas casas Mina-Nagô, este é o dia de se fazer uma "obrigação" denominada "almoço de Ogingê-Goru". Em termos profanos, uma feijoada de feijão-preto acompanhada de caranguejos cozidos na água e sal ${ }^{15}$. Que conotação sagrada cerca esses alimentos tão prosaicos? Para a Mina-Nagô o caranguejo é uma proibição alimentar das mais severas, especialmente para os filhos de Omolu/Obáluaiê ou Iansã, enquanto que o feijão-preto com toucinho pode ser um "ajeum" (comida) servido em dia de festa de Obáluaiê.

Na mitologia Nagô, Obáluaiê é filho de Nanã-Buruku ou Boroquê, a primeira esposa de Oxalá. Nas várias versões dos mitos e lendas acerca desse orixá, consta que Obáluaiê nasceu leproso, razão pela qual foi repudiado por sua mãe, que o joga na lama, onde ele é atacado por um caranguejo que começa a devorar suas carnes. Obáluaiê por certo iria morrer, quando surge Iemanjá, que o salva curando-o com óleos da folha de bananeira. Mesmo assim, ele fica marcado com o corpo asqueroso, porque coberto de feridas, razão pela qual se esconde debaixo de seu "filá", sua veste ritual de palha.

Porque Obáluaiê quase foi morto por um caranguejo, nenhum de seus "filhos" comem esse animal; por conseguinte, "certas quizilas são explicadas pela importância que determinada substância teve na história mítica do Orixá" (AUGRAS, 1987, p. 72). Mas, como explicar o fato de o caranguejo também ser uma proibição alimentar para as pessoas que carregam "Iansã"? Uma lenda recolhida por Augras (1983, p. 128-9) nos conta que certo dia de festa todos os deuses estavam dançando, menos Omolu, que ficara fora com medo de aparecer em público por causa de suas pústulas. Auxiliado por Ogum, que o ajuda a se disfarçar sob suas vestes de palha, Omulu cria coragem e entra na sala, mas ninguém queria dançar com aquela figura, porque todos sabiam, de antemão, que ela era asquerosa.

Somente Iansã, por ser altiva e corajosa, dançou com Omulu e, junto com ele, o turbilhão dos ventos, já que Iansã reina nos ventos. E quando os ventos levantaram as vestes de Omulu, todos os presentes, surpresos, viram que debaixo do "filá" se escondia o corpo de um homem jovem e belíssimo, sem nenhum defeito. Em recompensa pelo seu gesto, Iansã recebeu de Omulu o poder de reinar sobre os mortos.

Novamente a história mítica nos ajuda a encontrar ligações entre Iansã e Omulu: talvez por "respeito", os "filhos" de Iansã também deixaram de comer o caranguejo (ibidem: 1987, p. 72). Sucede que, até agora, nunca encontrei essa rica e bela mitologia africana nos terreiros de Belém. Dos mitos e lendas dos orixás, apenas fragmentos são lembrados, ainda que no Mina-Nagô também se reconheça a genealogia dos orixás e, sobretudo, se respeite suas "quizilas", onde o caranguejo aparece como um "preceito" entre o "povo

\footnotetext{
15 Esse almoço pode ter caráter solene ou uma feição absolutamente profana, confundindo-se com a "caranguejo a toctoc", um tipo de almoço domingueiro regado a cerveja e que é um lazer muito apreciado em Belém. Participamos de um desses almoços com uma "filha" de Iansã e outra de Omulu; a primeira comia o caranguejo com muito gosto ao mesmo tempo que quebrava as carapaças do animal dizendo, em brincadeira, que "quebrava as forças do inimigo". Explicava ela que sua maior "quizila" era o jabuti, porque também era "filha" de Xangô. A "filha" de Omulu limitava-se a provar, com ar de muita repugnância, as pernas menores e mais finas do animal.
} 
de santo" de Belém ${ }^{16}$. Então, por que razões no Mina-Nagô o caranguejo se torna um banquete sagrado exatamente na Quinta-Feira Santa?

Certamente que em tradições de origem sincrética, tais como a Mina-Nagô, essas formas africanas de reparar e organizar a dinâmica do mundo - e na qual as quizilas e os preceitos fazem sentido - há muito foram reinterpretadas; Penso que, por influência do catolicismo, o grande tema expresso na Quinta-Feira Santa é também o tema da morte. A liturgia dos terreiros coloca em primeiro plano orixás como Omulu/Obaluaiê, Iansã, animais como o caranguejo, todo um conjunto de elementos que, nos mitos e lendas originais, está direta ou indiretamente associado à temática da morte. Mas, quando perguntei das razões de tamanha abominação pelo caranguejo, ninguém forneceu qualquer explicação que estivesse ligada à mítica africana.

Não obstante, o depoimento das pessoas deixou claro que aquele animal, neste novo contexto sincrético, continuava associado a imagem da morte. Com reações de repugnância, o caranguejo foi repetidamente descrito como um bicho nojento que devia ser evitado porque "vivia na lama" e porque "come entranhas". O fato de o animal alimentar-se de toda sorte de detritos orgânicos evocava nas pessoas a imagem de um animal que é capaz de comer um cadáver em decomposição. Essa imagem revelava uma espécie de "horror aos mortos", que na realidade era um horror mais aplicado ao defunto propriamente dito do que à alma do morto.

Outras vezes, a evitação se fundamentou numa observação da natureza metonímica remetida ao sucesso individual, pois foi dito que o caranguejo é um "animal que anda para trás", e que, portanto, comê-lo é arriscar a própria vida "andar para trás, como um caranguejo". Mas, sem dúvida, a associação, o orixá e a morte podem ser observadas durante a cerimônia do sepultamento dos "filhos" de Iansã, ocasião em que a marcha do cortejo fúnebre, por estranha coincidência, repete o mesmo movimento de locomoção daquele animal: dois passos para frente e um para trás.

Se o caranguejo evoca a condição de finitude humana, pensamos que talvez a sua evitação possa ser entendida como uma espécie de evitação do enfrentamento inexorável da morte. Nesse sentido, a QuintaFeira Santa, por ser o dia de rompimento desse tabu. Se torna uma espécie de "pedagogia da morte", e onde a liturgia é didaticamente perfeita porque faz com que as pessoas falem de um tema que normalmente não falariam caso não existisse essa liturgia.

\section{Sexta-Feira da Paixão}

\footnotetext{
${ }^{16}$ Embora sem igual rigor. Certos "filhos" de Iansã não o comem nunca e enfatizam: "Caranguejo não passa nem da porta de casa!" Outros respeitam o tabu apenas em dias de "trabalhos" e "preceitos". Em certa casa Mina-Nagõ não se come caranguejo nos meses que tem a letra "r" no seu nome - o caranguejo é comido somente em maio, junho e julho.
} 


\section{Um estudo do sincretismo religioso em Belém do Pará}

É o dia de se fazer a "arreada" da "mesa de Oxalá", cerimônia que, embora apresentando pequenas variações, consiste basicamente em se estender, no centro do espaço de dança do terreiro, uma toalha branca no mesmo formato do pálio ("alá") de Oxalá. Arruma-se sobre essa toalha: água, vela branca, vinho, copos e/ou taças, pedaços de pão comum. Essa é uma cerimônia restrita aos "filhos" da casa, ocasião em que, em torno daquela mesa posta no chão, o pai/mãe e todos os seus "filhos" vão "beber daquele vinho" e "comer daquele pão", numa espécie de ceia privada.

Perguntado sobre a finalidade da oferenda, um jovem zelador-de-santo mina-nagô explicou:

A finalidade é um tipo de fortificação também, que o pão representa o corpo, não é? E o vinho representa o sangue, então, uma purificação naquele dia para mim principalmente que sou o primeiro que como (...) pedir algo para nós ou que Oxalá nos perdoe de alguma falta e então nossa fé vai naquilo, nossa saúde, problema de doença e, graças a Deus, a gente alcança (Pai Beto - Liderança Mina Nagô, 1986)

A "mesa" é arrumada das 12 às 15 horas, no exato momento em que na Igreja Católica se faz a pregação do Sermão das Três Horas da Agonia, rememorando Cristo agonizante na cruz. Nos terreiros, a Sexta-Feira Santa é um dia de jejum e de retiro. O clima é de oração, de silêncio, de contrição e quietude: os tambores estão cobertos e silentes, e não se liga rádio. A Sexta-Feira é especialmente um dia de profunda meditação, arrependimento e perdão, pois é o dia em que os "filhos" devem ser dirigir a "casa de santo" para pedir a benção de seu pai/mãe e ouvir sua preleção. O teor dessa preleção, nas palavras dos próprios zeladores de santo:

Falamos só sobre Cristo, salvamos, falamos sobre a vida de Cristo, o perdão (...).

(...) Aí os filhos vêm vindo, eles dá a benção, o pai-de-santo tá puro, conversa coisas boas, pede por aquilo que fez e não devia ter feito, por aquele erro que cometeu. Alguns relatam: o senhor me perdoa por isso assim; então o pai, aquele dia é um dia consagrado praquilo, o pai vai, bota a mão na cabeça, faz aquela prece pedindo aos orixás que protejam os seus lares, as suas famílias (...) (Pai Beto - Liderança Mina Nagô , 1986)

Esse sentimento de culpa que se expressa na liturgia da "mesa de Oxalá" é, de certa forma, a antevéspera de punição e da penitência que vão acontecer no Sábado de Aleluia.

\section{O Sábado de Aleluia}

É o dia de "disciplina" do médium, ocasião em que ele vai expiar as faltas que cometeu durante o ano. Mas também é o dia de retorno das entidades ausentes do convívio dos homens desde o Carnaval. A maior ou menor ênfase em cada um desses significados depende das normas e tradição de cada casa. Todavia, qualquer que seja a tradição, tem-se como certo que a Aleluia rompe sempre pela manhã, havendo aqui um descompasso com a marcação do tempo católico, onde a Aleluia rompe a noite de Sábado Santo por ocasião da Vigília Pascal. Os terreiros, divergindo da Igreja, mantiveram-se alinhados com a tradição folclórica da "Malhação de Judas"17.

\footnotetext{
${ }^{17}$ Judas são bonecos de pano com enchimento de palha que são rasgados ou queimados em clima de lazer, nos bairros de Belém. Geralmente são pendurados nos postes antes de serem estraçalhados pelos moradores do bairro onde ocorre a manifestação. O boneco, orginalmente uma representação do mal e da traição associados à Judas Escariotes, atualmente
} 
Nas tradições em que se dá maior ênfase à Aleluia como dia de "pagamento" das faltas, duas são as formas de "disciplinar" os médiuns: o "bolo da felicidade" e a "peia na pedra". Ambas ofendem o corpo, mas enquanto a primeira é um castigo corporal mais leve, a segunda é mais violenta.

No "bolo da felicidade" os médiuns, homens e mulheres em fila, diante do pai ou da mãe do terreiro, estendem as mãos para receberem uma sequência de bolos de palmatória aplicados pela entidade, geralmente um caboclo homem ou mulher que seja bastante popular no "Pai" ou "Mãe" de santo do terreiro. Acredita-se que esse "castigo" traga sorte para aquelas pessoas que apanham.

A "Peia na Pedra" é um castigo corporal mais pesado, por vezes muito violento em que o/a médium de joelhos, levanta e desce seu corpo em movimentos rápidos batendo no chão com as mãos espalmadas. A repetição do movimento faz inchar as mãos e não raro "tirar sangue" dos cantos das unhas. A idéia dessa "peia na pedra" é a de um castigo aplicado por uma das entidades do próprio médium. O "pai ou mãe de santo" do médium não pode impedir essa punição da entidade, ainda que o castigado seja seu "filho ou filha de santo", pois trata-se de dívida entre o médium e sua entidade. Ao "Pai ou mãe de santo", cabe apenas com gestos rituais, pedir uma "misericórdia" pelo filho/filha castigado.

Essas duas formas de "disciplina", coletivas, acontecem por ocasião do "tambor de Aleluia", uma cerimônia realizada de forma semiprivada, quando ocorre de dia, e pública quando ocorre à noite. A sequência ritual consiste sempre nas mesmas etapas: a) uma "abertura" do "toque"; b) canta-se para "salvar" a Aleluia; c) canta-se para Ogum e Euá - os orixás que vão "buscar" a Aleluia. d) a "peia" propriamente dita; e) término da "peia" e retorno das entidades que voltam a "baixar" na cabeça dos "filhos". Este é um momento marcado por grande euforia e a partir daqui as entidades chegam para "brincar" (LEACOCK, 1964).

A "disciplina" da "peia" não isenta os pais/mães-de-santo; ao contrário, eles são os primeiros a se submeterem à "peia" e, não raro, mais de uma vez. Também é muito recorrente as duas formas de castigo se sucederem no decorrer do "tambor", isto é, após a "peia na pedra" segue-se a sessão do "bolo da felicidade", que já se realiza no clima de alegria do retorno das entidades. De modo geral, os médiuns preferem se submeter a esses castigos corporais na humilhação pública do "tambor de Aleluia" do que sofrer uma "peia do tempo"18, considerada a pior forma de castigo.

Como se pode observar, temos aqui a penitência caracterizando tanto a Quaresma dos terreiros quanto a Quaresma da Igreja, obviamente, com duas vivências distintas desse tempo penitencial. É que do lado católico, através da Bula Papal de Paulo VI de 17/02/1966 (adaptada ao Brasil pela CNBB), houve uma mitigação do corpo, uma vez que se conservou como penitência o jejum e a abstinência apenas na QuartaFeira de Cinzas e na Sexta-Feira Santa. Diminuiu-se, assim, a penitência corporal conclamando-se os fiéis

passou a representar o mal da corrupção na política e, de um único boneco, passou a personificar um grupo de políticos que por seu envolvimento com roubo são "mortos" na via pública"

${ }^{18}$ A "Peia de tempo" ocorre no cotidiano do médium; pode acompanhá-lo durante bastante tempo de sua vida fazendo-o entender que as coisas não dão certo pela existência de dívida ou de dívidas a serem pagas. 
preferencialmente a "metanóia", conversão ou mudança da vida interior. Enquanto isso, o "povo de santo" parece ter conservado práticas anteriores às muitas reformas da Igreja, pois o comportamento do pai-desanto, que "apanha" em primeiro lugar para depois ser imitado por seus "filhos", relembra a prática litúrgica do cristianismo primitivo, quando, durante a Quaresma, o clero era o primeiro a se submeter às mesmas humilhações dos penitentes públicos para confortá-los e encorajá-los a seguir seu exemplo (DIX, 1945). A comparação não pretende, no entanto, ver essa prática como uma "sobrevivência"; ela é apenas uma homologia significativa.

$\mathrm{Na}$ tentativa de encontrar as comunicações entre os dois sistemas, me parece útil retomar o ritual "mesa de Oxalá" e a concepção da Aleluia como o dia que marca o retorno dos deuses ao convívio dos homens. Isto porque é muito intrigante constatarmos que quando, na liturgia católica, Jesus agoniza, nos terreiros se "arreia" uma obrigação, como a "ceia" de Oxalá. A questão inicial é sabermos quem é Oxalá para o "povo de santo". Para o sistema de crenças Nagô, Oxalá é o deus responsável pela criação dos seres humanos que povoam o mundo material. Ele é o deus de todos os começos e de todas as realizações: a vida e a morte se obrigam sob o seu pálio.

Oxalá é o princípio da vida, ele é aquele que não morre porque é o dono da vida (ARAIA, s/d, p.126). Para os "mineiros", Oxalá, como qualquer outro orixá, é simplesmente "natureza", isto é, aquilo que não morre porque nunca viveu como nós, humanos. Nestes termos, o associar a Cristo com Oxalá e celebrálo no mesmo momento em que Cristo agoniza não podem ser vistos como a afirmativa dos terreiros de que Cristo não morreu ou, ainda, a negação da possibilidade de sua morte? De fato, quando perguntei a uma notória umbandista: "Quer dizer que Ele (Jesus Cristo) não morreu?", ela me respondeu, absolutamente convencida do que dizia "Não morreu, Jesus Cristo não morreu, e na presença do povo Ele morreu, mas Ele não morreu, Ele está vivinho como está" (Mãe Francinete - Liderança Umbandista - 1986). E insistia na afirmação de que Jesus Cristo, tal como Oxalá, era "natureza".

Talvez eu não tivesse percebido o que aquela mulher afirmava com tanta convicção caso não me lembrasse de que a ideia de um Cristo homem que não morre estivera também presente no pensamento cristão do gnosticismo. A diferença estava no fato de que, enquanto gnósticos se apoiavam na filosofia grega do neoplatonismo para sustentar que o corpo de Cristo era apenas uma imagem ou uma mera aparência de algo que era eterno, os terreiros se apoiavam em tradições africanas, em princípios como "força", "axé", "natureza", para engendrar uma interpretação própria sobre a morte de Cristo. Por essa razão, penso agora que, quando um umbandista também se diz "católico", e um pai-de-santo, embora negando sua "catolicidade", não dispensa suas "obrigações" e penitências da Semana Santa, em ambos os casos eles não estão fingindo ou simplesmente manipulando identidades, mas, na verdade, parecem ter algo de muito pertinente a dizer, e com o mesmo direito com que Orígenes, no século IV, se considerava cristão, apesar de suas diferenças com a ortodoxia.

Pode-se, porém, questionar que tanto a liturgia simbólica da Paixão quanto a da Aleluia, mais do que falar em Cristo/Oxalá, estão, isto sim, dramatizando ao extremo o afastamento e o retorno das entidades, 
e, nesse sentido, o "tríduo" dos terreiros não faria nenhuma comunicação entre os dois sistemas de crenças. De fato, durante a "mesa de Oxalá", é uma réplica do seu "alá" (pálio) que está no chão apontando simbolicamente para o vazio da ausência das entidades. E a ausência cria, como vimos, uma "fraqueza" no duplo sentido de uma concepção que não é verdadeiramente católica: $1^{\circ}$ ) da falta de "força" e da "desproteção"; $2^{\circ}$ ) da fraqueza moral (expressa pela linguagem do reconhecimento e da confissão da culpa), a qual, diga-se de passagem, não é a mesma natureza de culpa que recai sobre a humanidade no decorrer da Semana Santa.

Mesmo assim, não seria o tema do afastamento/retorno uma visão paralela de um tema cristão? Lembremos do que se encontra nas Sagradas Escrituras (Jo 14, 12-16), quando Jesus se despede dos seus discípulos dizendo: "Vou para o meu Pai e de lá enviarei outro Consolador" (Espírito Santo Paráclito), o que de fato aconteceu 50 dias depois (Pentecostes) após sua ascensão (At. 2, 1-11). Então, a ideia de deuses e de heróis que se afastam temporariamente dos homens para depois retornar ao seu convívio não parece ser algo também cabível dentro do mito cristão? Mas, se do ponto de vista católico (oficial, bem verdade), a cristandade continua esperando a segunda vinda do Messias, e o seu retorno passa pelo lado da história, da promessa e da esperança do Reino que ainda vai chegar, essa dimensão é reduzida ao mínimo na versão dos terreiros, onde o retorno já acontece, de fato, no Sábado de Aleluia.

\section{CONCLUSÕES}

$\mathrm{O}$ esforço deste trabalho foi o de deixar claro que aquilo que chamamos de sincretismo ou "mistura" não se limita a uma associação superficial entre santos e orixás, mas que o sincretismo possui substância e densidades próprias. Nesses termos, ele também não se reduz a uma "máscara" que as pessoas colocam ou retiram segundo regras de um jogo político. Aparentemente incoerente, ele mobiliza um conjunto de ideias e interpretações em torno de temas existenciais, implicando várias tradições em jogo.

Parece significativo que na semana em que Cristo, o Messias, está morrendo, é o tema da morte que, numa linguagem altamente elaborada, também está em questão nos terreiros. Esta concordância evidencia, então: a) que tanto a Igreja quanto os terreiros comentam o mesmo tema - a morte -, produzindo duas versões ou variações desta condição humana; b) que ambos - igrejas e terreiros - são capazes de partilhar e reconhecer um mesmo tempo sagrado. Ao descrever o que chamei de "liturgia simbólica" penso ter deixado claro que, apesar de reunir princípios de outro(s) sistema(s), os cultos sincréticos, a exemplo do Mina-Nagô, não se reduzem a uma justaposição grosseira, mas, ao contrário, são capazes de reunir esses princípios numa unidade que no seu ecletismo é nova e criadora.

Quanto ao desprezo pela "mistura" a que me referia no início deste trabalho, penso que essa postura analítica está ancorada num duplo suposto cultural que, diga-se de passagem, não é válido para todas as religiões: $1^{\circ}$ ) a ideia de que o "puro" é sinônimo de bom, enquanto o "impuro" significa corrompido, ou, ainda, a ideia de que "pureza" é superior a "mistura"; $2^{\circ}$ ) a ideia de que coerência e ecletismo se opõe irremediavelmente. Para muitos analistas e mesmo adeptos dos cultos afro-brasileiros, a coerência é sem 
dúvida a forma justa de se ver e de se pensar. Sucede que, às vezes, como no exemplo que acabamos de apreciar, ela, a coerência, está escondida ou pode ser de outra natureza daquele pensamento unívoco presente na geometria cartesiana e na sistemática das doutrinas teológicas.

\section{REFERÊNCIAS BIBLIOGRÁFICAS}

ADAM, Adolf. O ano litúrgico: sua história e seu significado segundo a renovação litúrgica. 2a ed; São Paulo, Edições paulinas, 1982 (Coleção Liturgia e Teologia 6).

ARAIA, Eduardo (ed.). Cultos afro-brasileiros. (3 ${ }^{\mathrm{a}}$ parte O - Z). São Paulo, Editora três, s/d.

AUGRAS, Monique. O Duplo e a Metamorfose. a identidade mítica em comunidades nagô. Petrópolis, Vozes, 1983.

Quizilas e preceitos - transgressão, reparação e organização dinâmica do mundo". In:

MOURA, C. E. M., org. Candomblé - Desvendando identidades, São Paulo: EMW Editores, 1987, p. 53-86.

BIRMAN, Patrícia. Comentários a propósito da II conferência Mundial da Tradição dos orixás. Comunicações do ISER, Rio de janeiro, ISER, 8, 1984.

DANTAS, Beatriz Góis. Vovô Nagô e papai branco. Dissertação de mestrado UNICAMP, 1982, mimeo.

DIRETÓRIO LITÚRGICO (1988). Conferência Nacional dos Bispos do Brasil (CNBB), São Paulo, Edições Loyola. 1987.

DIX, Gregory (Dom). The Shape of the Liturgy. Westminster e Londres. Dacre Press, 1945

FRY, Peter. De um observador não participante. Reflexões sobre a II Conferência Mundial da Tradição dos Orixás e Cultura, Comunicações do ISER, Rio de janeiro, ISER, 8, ano 1984.

FURYA, Yoshaki. "Nagoização" e "umbandização" - uma síntese no culto Mina-Nagô de Belém, Brasil. Universidade de Tóquio, 1986.

KLOPPENBURG, Boaventura. Sincretismo. Comunicações do ISER. Rio de Janeiro. ISER, 81984.

LEACOCK, Seth. (1964). Fun-Loving Deities in an Afro-Brazilian cult. Anthropological Quarterly, 37, 94109, 1964.

MOTTA, R. Sincretismo Religioso Afro-brasileiro x Pureza Africana. In: Relatório do Simposium Religião e Negritude: Identidade e Resistência Cultural do Negro Brasileiro. São Luís, Universidade Federal do Maranhão (UFMa) e Núcleo de Estudos Afro-Brasileiros (NEAB), 1985.

POLLAK-ELTZ, Angelina. Cultos Afroamericanos: (Vudu y Hechiceria en las Americas). Caracas, Universidade Católica Andres Bello, 1977.

RINGGREN, H. The Problems of Syncretism in Syncretism: In HARTMAN'S, S. (ed) Syncretism Stockholm e Uppsala, Almqvist \& Wiskell, 1969.

Texto recebido em: 10/11/2020

Texto aprovado em: 20/11/2020 